\title{
Identification and Isolation of a Platelet GPIb-like Protein in Human Umbilical Vein Endothelial Cells and Bovine Aortic Smooth Muscle Cells
}

\author{
Adam S. Asch, Burt Adelman, ${ }^{*}$ Masafumi Fujimoto, and Ralph L. Nachman \\ Specialized Center for Research in Thrombosis, Division of Hematology-Oncology, Cornell University Medical College, New York \\ 10021; and *The Medical College of Virginia and Hunter Holmes McGuire Veterans Administration Hospital, Richmond, Virginia 23249
}

\begin{abstract}
Glycoprotein Ib (GPIb) is an intrinsic platelet membrane protein that plays a major role in platelet adherence and mediates ristocetin-dependent platelet von Willebrand factor binding. Recent reports that the platelet membrane glycoprotein complex IIb/IIIa is expressed in several cell types prompted us to look for GPIb expression in other vascular cells. Immunoperoxidase staining of human stomach and skin histologic sections with polyclonal as well as monoclonal anti-GPIb antibody revealed the presence of GPIb in the endothelial cell and smooth muscle cell layers. Western blotting using monospecific polyclonal anti-GPIb antibodies confirmed the presence of immunoreactive GPIb in human umbilical vein endothelial and bovine aortic smooth muscle cell cultures. Fab fragments of a monoclonal anti-GPIb antibody were used to immunoprecipitate $\left[{ }^{3} \mathrm{H}\right]$ leucine labeled GPIb from metabolically labeled cells. The GPIb in these cells was functional as measured by ristocetin-dependent cell agglutination and by vWF binding. Endothelial cells as well as smooth muscle cells bound ${ }^{125}$ I-labeled vWF in a ristocetin-dependent manner, with a $K_{d}$ of $7.9 \mathrm{nM}$.
\end{abstract}

\section{Introduction}

Glycoprotein Ib (GPIb) ${ }^{1}$ is a $165-\mathrm{kD}$ intrinsic platelet membrane protein composed of disulfide linked alpha (145 kD) and beta $(22 \mathrm{kD})$ chains $(1)$. Glycoprotein $\mathrm{Ib}$ is a platelet receptor for the von Willebrand factor (vWF) and plays a major role in mediating platelet adhesion to the subendothelium (2). In resting platelets, the membrane glycoprotein is linked to the cytoskeleton (3-5).

Recently, the glycoprotein IIb/IIIa complex, another intrinsic platelet membrane receptor complex, which mediates platelet aggregation, has been described in cells other than platelets. GPIIb/IIIa-like molecules are present in endothelial cells, smooth muscle cells and fibroblasts (6-8). The broad tissue distribution of IIb/IIIa and the emerging homologies

Address reprint requests to Dr. Asch, Division of Hematology-Oncology, Cornell University Medical College, 1300 York Avenue, New York, NY 10021.

Received for publication 19 March 1987 and in revised form 8 October 1987.

1. Abbreviations used in this paper: GP, glycoprotein; HBS, Hepesbuffered saline; HUVEC, human umbilical vein endothelial cell; TBS, Tris-buffered saline.

J. Clin. Invest.

(C) The American Society for Clinical Investigation, Inc.

$0021-9738 / 88 / 05 / 1600 / 08 \$ 2.00$

Volume 81, May 1988, 1600-1607 between adhesive protein receptors of various tissues prompted us to explore the possibility that GPIb might be similarly broadly distributed.

\section{Methods}

Materials. Sephacryl S-1000, Sepharaose 4B, and PD 10 column (Sephadex G-25 M) were obtained from Pharmacia Fine Chemicals, Uppsala, Sweden. $\mathrm{Na}^{125}$ I was purchased from New England Nuclear, Boston, MA. Human plasma was obtained from the New York Blood Center. Fetal calf serum was purchased from Flow Laboratories (Mclean, VA), tissue culture flasks from Corning Glassware, Inc. (Corning, NY), fungizone from E. R. Squibb \& Sons, Inc. (Princeton, $\mathrm{NJ}$ ), ristocetin sulfate from Lenau and Co. (Copenhagen, Denmark), calf skin gelatin from Eastman, sodium meta-bisulfite and EDTA from J. T. Baker Chemical Co. (Phillipsburg, NJ), and endothelial cell growth factor (ECGF) from Meloy Laboratories, Inc. (Springfield, VA). Medium 199, modified Eagle's medium, l-glutamine, penicillinstreptomycin solution, and trypsin-versene mixture were purchased from Whittaker M. A. Bioproducts (Walkersville, MD). Hepes, bovine serum albumin (BSA, 35\% solution), heparin, gelatin, chloramine-T, polyethyleneglycol (PEG), and antialbumin antiserum were purchased from Sigma Chemical Co., St. Louis, MO.

Antibodies. Glycocalicin was prepared as previously described. A monospecific polyclonal anti GPIb was prepared by immunizing rabbits with glycocalicin, a calpain cleavage product of the alpha chain of GPIb. The monoclonal antibody $3 \mathrm{G} 6$ was prepared by standard techniques (9) from mice immunized with purified glycocalicin. Both polyclonal and monoclonal antibodies demonstrated GPIb alpha specificity in whole platelet membrane Western blots. The polyclonal antibody blocked ristocetin-induced platelet agglutination in platelet-rich plasma without affecting ADP-, collagen-, thrombin-, or epinephrineinduced platelet aggregation. 3G6 monoclonal did not inhibit ristocetin-induced platelet aggregation. For some studies, AP1, a monoclonal antibody that inhibits ristocetin-induced platelet aggregation (kindly furnished by Dr. T. Kunicki, Milwaukee Blood Center), was used (10). For some studies a second monospecific-polyclonal antibody prepared to reduced-alkylated GPIb-alpha was used (kindly furnished by Dr. $Z$. Ruggeri, Scripps Institute, La Jolla, CA) (11).

$v W F$ purification. $v W F$ was purified by a modification of the procedure of Michelson et al. (12). $10 \mathrm{U}$ of cryoprecipitate obtained from the New York Blood Center was resuspended in $20 \mathrm{mM} \mathrm{Na}$ citrate and the $\mathrm{pH}$ was adjusted to 6.1 with $20 \mathrm{mM}$ citric acid. $40 \%$ PEG (wt/vol) was added to give a final concentration of $2 \%$ and the resulting precipitate discarded. Additional PEG was added to a final concentration of $12 \%$ and the precipitate collected by centrifugation at $5,000 \mathrm{~g}$ for 20 min. The pellet surface was washed once with $10 \mathrm{ml}$ of ice-cold $0.05 \mathrm{M}$ Tris, $0.15 \mathrm{M} \mathrm{NaCl}, 8 \%$ ethanol, $\mathrm{pH} 7.8$ in order to remove residual PEG, and washed again with $10 \mathrm{ml}$ of $50 \mathrm{mM}$ Tris $0.15 \mathrm{M} \mathrm{NaCl}$, and $0.02 \% \mathrm{NaN}_{3}, \mathrm{pH} 7.8$ (TBS). The pellet was warmed to $37^{\circ} \mathrm{C}$, suspended in TBS, and applied to a $2.5 \times 100 \mathrm{~cm}$ siliconized glass column containing Sephacryl S-1000 after removing insoluble materials by centrifugation. 4-ml fractions were collected at a $40-80-\mathrm{ml} / \mathrm{h}$ flow rate and analyzed for protein concentration by following absorbance 280 $\mathrm{nm}$. Immunoreactivity of the fractions with monospecific anti-vWF antibody was followed by ELISA. Fractions demonstrating VWF immunoreactivity were pooled and concentrated by precipitation with 
$35 \%(\mathrm{wt} / \mathrm{vol}$ ) ammonium sulfate followed by centrifugation at 20,000 $g$ for $30 \mathrm{~min}$ at $4^{\circ} \mathrm{C}$. The precipitate was then resuspended in a small volume of TBS and applied to a $2.5 \times 40-\mathrm{cm}$ Sepharose 4B column. 2-ml fractions collected at a flow rate of $40 \mathrm{ml} / \mathrm{h}$ were analyzed for vWF as described above. Immunoreactive fractions were pooled and reprecipitated with $35 \%$ ammonium sulfate. The precipitate was resuspended in 1-2 ml of TBS, pH 7.4, and dialyzed against TBS overnight at $4^{\circ} \mathrm{C}$. The purity of the vWF was $>90 \%$ when analyzed by SDSPAGE.

Cells. Human umbilical vein endothelial cells (HUVEC) were obtained from cords and maintained in culture for one to three passages for these studies as previously described (13-16). Early passage bovine aortic smooth muscle cells were a kind gift of Dr. David Hajjar (Cornell University Medical College, New York). The primary bovine aortic smooth muscle cells were obtained from fresh aortic specimens and were cultured as previously published (17). The human T cell lymphocyte line SK, was a kind gift from Dr. Jeffrey Lawrence (Cornell University Medical College, New York).

Immunohistology. Surgical specimens for these studies were provided by the Department of Pathology, Hunter Holmes McGuire Veterans Administration Hospital. Tissues were fixed in $0.2 \mathrm{M}$ mercuric chloride, $0.13 \mathrm{M}$ sodium acetate, and $3.7 \%$ formaldehyde and then imbedded in paraffin before sectioning and staining. After deparaffinization and rehydration, sections were incubated in methanol containing $0.6 \%$ hydrogen peroxide to quench endogenous peroxidase activity. Nonspecific antibody binding was inhibited with nonimmune serum of the same species as the secondary antibody. Antibodies were diluted in buffer containing $10 \mathrm{mM}$ sodium phosphate, $0.15 \mathrm{M}$ sodium chloride, and $0.1 \%$ bovine serum albumin, pH 7.4 (PBS). Primary antibody staining was performed with monospecific polyclonal rabbit anti-GPIb as well as the monoclonal antiglycocalicin, 3G6. After washing in PBS the slides were incubated with a biotinylated second antibody, washed again, and incubated with avidin and biotinylated horseradish peroxidase. The slides were developed by exposure to the substrate 3-amino-9-ethylcarbozole and counterstained with hematoxylin.

Western blotting. 1\% SDS in PBS was used to prepare cell lysates from gel filtered human platelets, cultured human umbilical vein endothelial cells, cultured bovine aortic smooth muscle cells, and SK cells (a T-cell lymphocytic cell line). The cell lysates were electrophoresed in a 7.5\% SDS-PAGE, blotted onto nitrocellulose and probed with a monospecific polyclonal rabbit anti-GPIb antibody followed by detection using a peroxidase-linked second antibody.

Biosynthesis. Preconfluent T75 flasks of early passage HUVEC and bovine aortic smooth muscle cells were labeled with tritiated leucine at $75 \mu \mathrm{Ci} / \mathrm{ml}$ in leucine free growth medium for $20 \mathrm{~h}$ and then solubilized. Fab fragments of the monoclonal anti-GPIb antibody-3G6, conjugated to goat antimouse Sepharose beads were used to precipitate labeled immunoreactive material. The beads were eluted in 1\% SDS and run reduced on $7.5 \%$ SDS-PAGE before autoradiography.

Ristocetin agglutination. HUVEC were resuspended in culture flasks by trituration in PBS containing $10 \mathrm{mM}$ EDTA. The cells were fixed in 3\% formaldehyde in PBS for $30 \mathrm{~min}$ and then washed in PBS containing $0.1 \mathrm{M}$ glycine and resuspended in PBS. Agglutination was followed in standard platelet agglutination wells $(18,19)$ in a total reaction volume of $150 \mu \mathrm{l}$. Suspensions containing 150,000 cells in 50 $\mu \mathrm{l}$ were added to agglutination wells containing ristocetin alone (1 $\mathrm{mg} / \mathrm{ml}$ final concentration) or ristocetin plus purified $\mathrm{vWF}(20 \mu \mathrm{g} / \mathrm{ml}$ final concentration) or ristocetin and vWF in the presence of $20 \mu \mathrm{g} / \mathrm{ml}$ monoclonal anti-GPIb, AP1 (10). At $2 \mathrm{~min}$ the wells were photographed. Similar studies with ristocetin were also performed in the presence of normal plasma and plasma from a patient with severe von Willebrand's disease.

Binding studies. Purified vWf was radiolabeled with ${ }^{125} \mathrm{I}$ by the chloramine-T method (20). Binding experiments were performed according to the method of Kao (21) with minor modifications. The endothelial cells at confluency were washed with Hepes-buffered saline (HBS) once and incubated with $0.01 \%$ EDTA and $0.25 \%$ BSA in HBS for $15-20 \mathrm{~min}$ at $37^{\circ} \mathrm{C}$. The cells were harvested by scraping gently with a rubber policeman. The cell suspension was centrifuged for 10 min at $1,000 \mathrm{~g}$ to sediment the cells, which were then washed once with HBS. For some experiments, living cells were washed twice more in HBS before the binding studies. Fixed cells were prepared as described above and were used for binding studies after washing three times in HBS.

Binding studies were performed in duplicate at room temperature in 1.5-ml polypropylene tubes (Brickman). In most assays, the fixed cells $\left(2-4 \times 10^{5}\right.$ cells) were incubated with $5.0 \mu \mathrm{g} / \mathrm{ml}{ }^{125} \mathrm{I}-\mathrm{vWF}$, and $0.02 \% \mathrm{BSA}$ in the presence or absence of $1 \mathrm{mg} / \mathrm{ml}$ ristocetin. Incubations were started by the addition of ${ }^{125} \mathrm{I}-\mathrm{vWF}$. After $60 \mathrm{~min}$ mixing, $150 \mu \mathrm{l}$ of each assay mixture was layered on $300 \mu \mathrm{l}$ of a 1:1 mixture of silicon oil (Dow Corning 550 and 556; Dow Corning Corp., Midland, MI) and spun for $10 \mathrm{~min}$ in a microfuge (Beckman Instruments, Inc., Fullerton, CA). After a 50- $\mu$ l aliquot of supernatant was removed for quantitation of free ${ }^{125} \mathrm{I}-\mathrm{vWF}$, the rest was aspirated and the tips containing cell pellets were removed and bound radioactivity counted. Ristocetin-dependent binding was calculated by subtracting the binding observed in the absence of ristocetin from that in the presence of ristocetin.

\section{Results}

Antibody specificity. The specificity of the monoclonal antibody 3 G6 (raised against glycocalicin) and the polyclonal antibody raised to glycocalicin were examined in Western blots against purified glycocalicin and solubilized platelet protein. Results obtained with the monoclonal 3G6 are shown in Fig. 1. Similar specificity was obtained with the polyclonal antibodies (Figs. 3-5). In addition, in platelet aggregation studies, the polyclonal antisera specifically inhibited ristocetin induced platelet aggregation (data not shown). 3G6 did not inhibit ristocetin induced platelet aggregation. In some studies, the monoclonal antibody AP1, which inhibits ristocetin induced platelet aggregation, was used.

Immunohistology. Consecutive sections through human stomach were fixed and sectioned and stained with a monospecific polyclonal anti-GPIb antibody raised to glycocalicin or with nonimmune antibody. Peroxidase positivity indicating the presence of immunoreactive GPIb was present in the smooth muscle as well as endothelial cell layer of the arteriole and the venule (Fig. $2 a, b$ ). The reactivity of the smooth

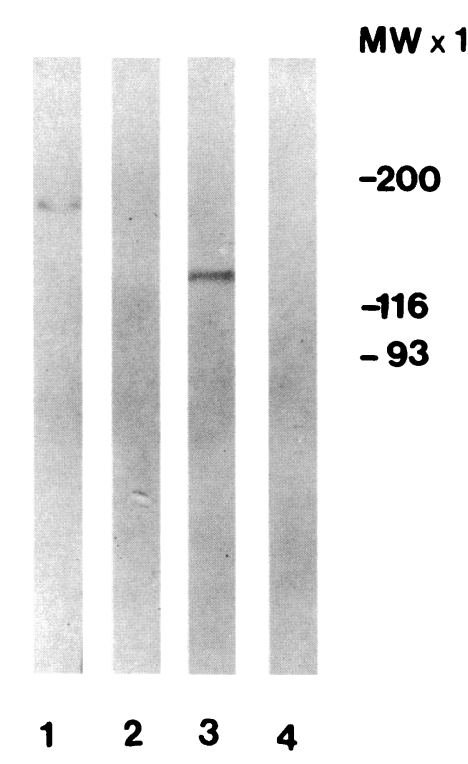

Figure 1. Western blot of solubilized platelet protein demonstrating antibody specificity. Whole platelets solubilized in SDS were run unreduced (lanes 1 and 2) or reduced (lanes 3 and 4 ) in a $7.5 \%$ SDSPAGE, blotted onto nitrocellulose and probed with 3G6 monoclonal (lanes 1 and 3), or with control ascites (lanes 2 and 4). A single band corresponding to the molecular weight of GPIb is detected by the monoclonal antibody. 

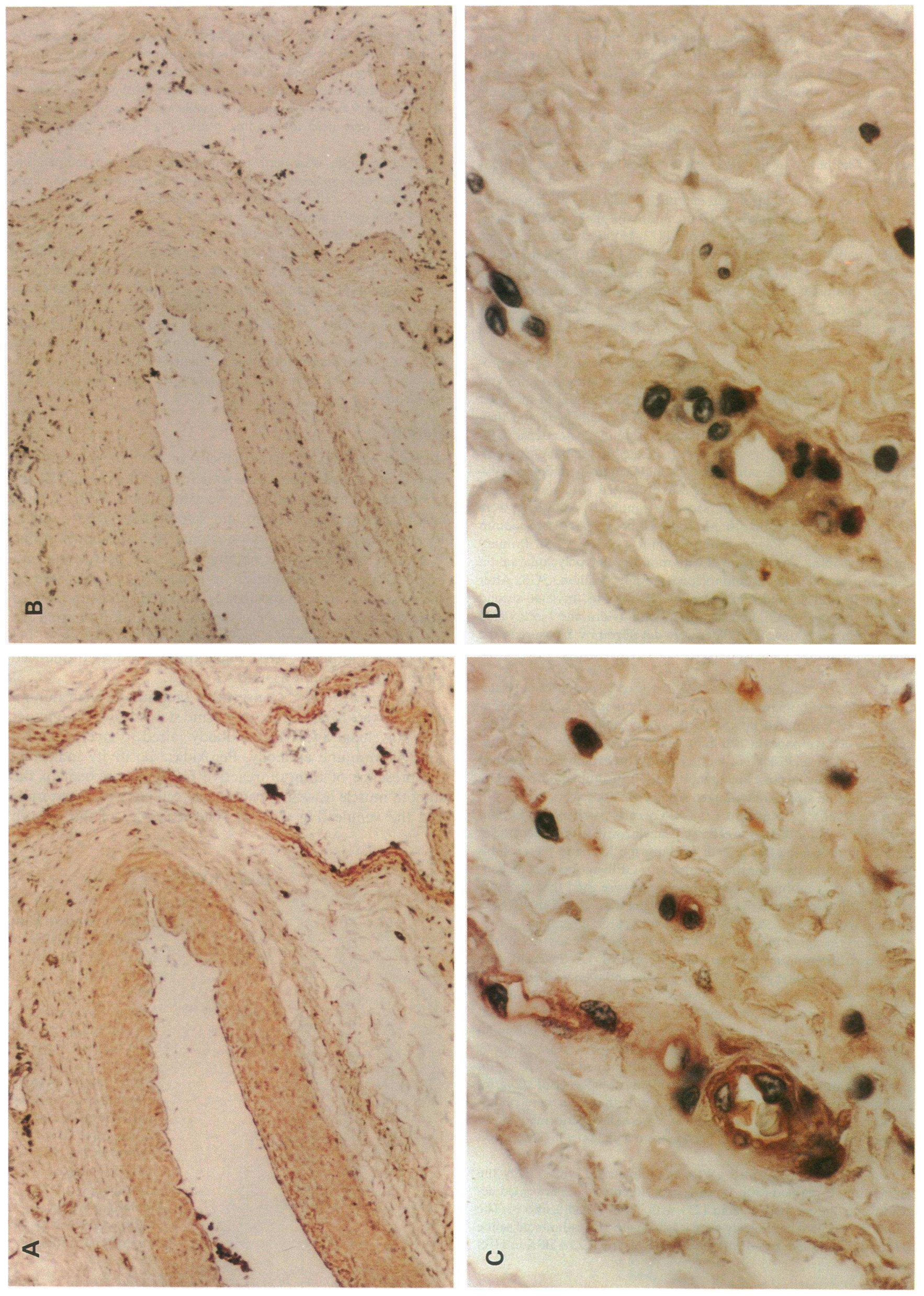


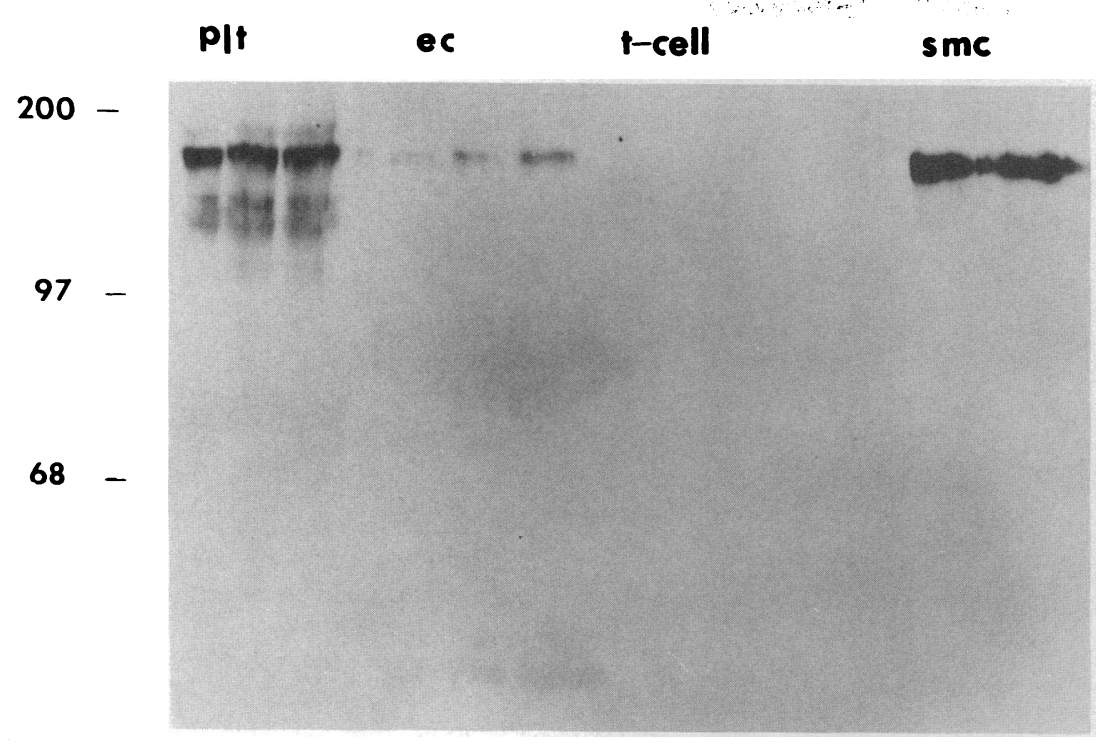

Figure 3. Western blot demonstrating cellular immunoreactive GPIb in unreduced cell lysates. plt, platelet lysate (three lanes). ec, endothelial cell lysate (three lanes). $t$-cell, $T$ cell lysate (three lanes). smc, smooth muscle cell lysate (three lanes). Both endothelial cell lysate and smooth muscle cell lysates contain immunoreactive GPIb that comigrates with platelet GPIb at $165 \mathrm{kD}$. In the platelet lanes, some lower molecular weight material is apparent and may correspond to proteolyzed GPIb. Similarly, the endothelial lanes contain some faintly positive bands which may represent proteolyzed GPIb. The T cell lanes are negative for any GPIb immunoreactive material.

muscle layer is demonstrated by the broad band of darker staining in Fig. 2 a. Similar sections through human subcutaneous fat were stained with the monoclonal anti-GPIb-3G6. Peroxidase product was present in capillary endothelium but not in surrounding tissue (Fig. $2 c, d$ ).

Western blotting. Western blotting of cell lysates was performed to further establish the cellular origin of the immunoreactive GPIb. In blots performed on unreduced whole cell lysates, probed with a polyclonal antibody raised to unreduced platelet glycocalicin, both endothelial cells and the smooth muscle cells demonstrated immunoreactive material that comigrated with unreduced platelet GPIb at $165 \mathrm{kD}$; the SK cell line was negative (Fig. 3). While blots of reduced platelet lysates revealed a single band of $150-\mathrm{kD}$, blots of reduced endothelial cell lysates did not demonstrate any immunoreactive material (Fig. 4) suggesting that the monospecific polyclonal antibody raised to glycocalicin recognized epitopes that were lost upon reduction of endothelial cell GPIb. Results with a second monospecific polyclonal antibody (11) that was raised to reduced and alkylated purified GPIb alpha were consistent with this. Western blots with the second antibody detected immunoreactive material in reduced as well as unreduced endothelial cell lysates (Fig. 5). The apparent molecular weight of unreduced endothelial cell GPIb was $165 \mathrm{kD}$, and increased to $170 \mathrm{kD}$ upon reduction, suggesting that it is a single chain molecule with intrachain disulfide bond(s). The immunoreactivity that was observed with this antibody, which recognizes colinear amino acid sequences within platelet GPIb-alpha, suggests that the GPIb-like molecule shares a significant degree of sequence homology with platelet GPIb-alpha.

Biosynthesis of radiolabeled GPIb. To examine the synthesis of GPIb by these cells, preconfluent flasks of human umbilical vein endothelial cells and bovine aortic smooth muscle cells were labeled with $\left[{ }^{3} \mathrm{H}\right]$ leucine and solubilized. Fab fragments of a monoclonal anti-GPIb were used to immunopre- cipitate labeled immunoreactive material and autoradiography was performed following separation by SDS-PAGE (Fig. 6). Both human endothelial, and bovine aortic smooth muscle cells synthesized a $150-\mathrm{kD}$ band that corresponds to the alpha subunit of GPIb. Bands at $60 \mathrm{kD}$ and at $30 \mathrm{kD}$ were seen in both cell lines. In addition, a band migrating with an apparent relative molecular mass $\left(M_{\mathrm{r}}\right)$ of 210 was observed in endothelial cells. It is possible that this may correspond to a $210-\mathrm{kD}$ GPIb-like molecule previously described in platelets (22). Control immunoprecipitation studies using normal mouse IgG failed to precipitate these specific bands.

Ristocetin agglutination. To examine the function of the GPIb-like molecule present in these cells, the ability of purified vWF and ristocetin to support the agglutination of endothelial cells was examined. In a manner analagous to platelet agglutination studies (23), cultured human umbilical vein endothelial cells were resuspended, fixed in $3 \%$ formaldehyde and washed and then incubated in the presence of $1 \mathrm{mg} / \mathrm{ml}$ ristocetin alone or with ristocetin plus purified vWF. Agglutination was ristocetin inducible, and vWF dependent, and was largely inhibited by an anti-GPIb monoclonal antibody, AP1, that inhibits ristocetin induced platelet agglutination (Fig. 7). These findings suggest that the GPIb expressed on these cells is functional as a ristocetin-dependent $\mathrm{vWF}$ receptor.

Binding studies. To examine more closely the function of the GPIB-like protein in these cells, we measured the binding of purified radiolabeled human vWF to cultured human umbilical vein endothelial cells, bovine aortic smooth muscle cells, and to the T cell line SK.

Binding of ${ }^{125} \mathrm{I}$-labeled vWF to HUVEC was ristocetin dependent, with a maximum effect at a ristocetin concentration of $1 \mathrm{mg} / \mathrm{ml}$ (Fig. 8). Binding to endothelial cells was saturable, and Scatchard analysis yielded a $K_{d}$ of $7.9 \mathrm{nM} \pm 2.9 \mathrm{nM}$ (Fig. 9). It is interesting to note that this value agrees well with those previously published for ristocetin dependent vWF binding to
Figure 2. Immunohistology. Sections through human stomach were probed with $(a)$ monospecific polyclonal anti GPIb antibody, or $(b)$ nonimmune antibody, and stained by immunoperoxidase. GPIb is demonstrated in the smooth muscle as well as endothelial cell layer of the arteriole and the venule. Sections of human subcutaneous fat were stained with $(c)$ the monoclonal $3 \mathrm{G} 6$, or with $(d)$ control ascites. Peroxidase product is present in capillary endothelium but not in surrounding tissue. 


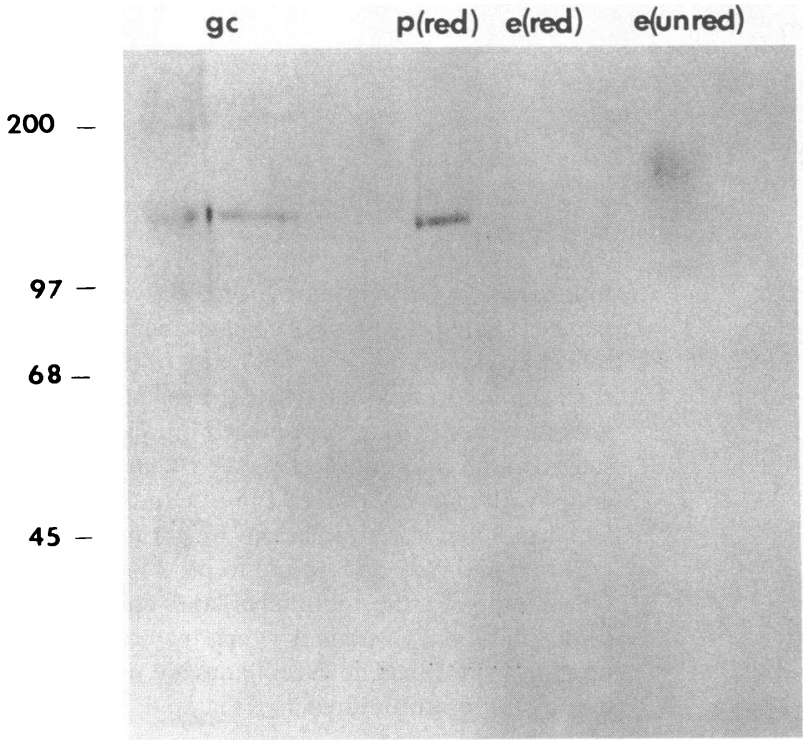

Figure 4. Western blot demonstrating immunoreactivity of reduced and unreduced endothelial cell lysates. Molecular weight markers in the left lane: myosin, glycocalicin, beta-galactosidase, ovalbumin, albumin. Lane $g c$, contains purified glycocalicin. Lane $p$ (red), contains whole platelet lysate run reduced, and demonstrates a single band at $150 \mathrm{kD}$ that corresponds to reduced GPIb. Lane $e($ red), contains endothelial cell lysate run reduced and shows a lack of immunoreactivity. Lane $e$ (unred), contains unreduced endothelial cell lysate and demonstrates a $165-\mathrm{kD}$ band similar to that seen in Fig. 3.

platelets $(21,24)$. The binding was specific, as it was inhibitable by excess cold vWF (Fig. $10 a$ ), excess cold glycocalicin (Fig. $10 b$ ), as well as anti-GPIb antisera (Fig. $10 c$ ). The $\mathrm{IC}_{50}$ of inhibition by cold vWF agrees well with the Scatchard-derived $K_{\mathrm{d}}$. The higher $\mathrm{IC}_{50}$ of glycocalicin suggests that its affinity for vWF may be less than that of native GPIb.

Similar studies were performed with bovine aortic smooth muscle cells and with the T cell line SK. Binding to smooth muscle cells was similar to that observed with endothelial cells

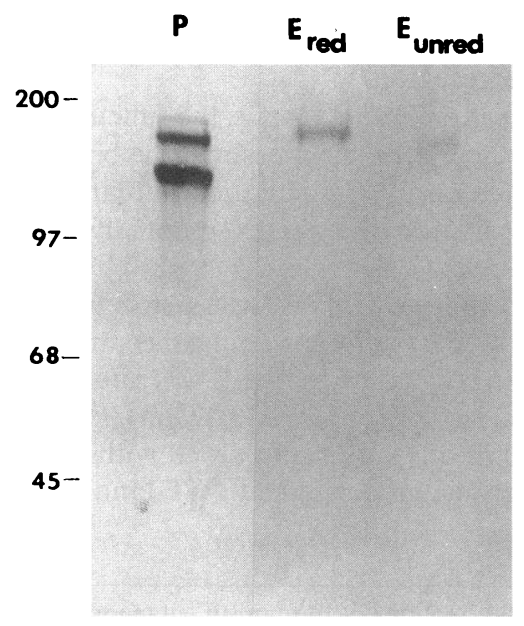

Figure 5. Western blot demonstrating immunoreactive GPIb-like material in reduced and unreduced platelet lysates. Lane $P$ contains whole unreduced platelet lysate plus purified glycocalicin. A band at $165 \mathrm{kD}$ corresponds to unreduced platelet

GPIb; a band at $150 \mathrm{kD}$ corresponds to purified glycocalicin. Lane $E_{\text {red }}$ contains reduced endothelial cell lysate and demonstrates a band with an apparent molecular weight of 165

$\mathrm{kD}$. Lane $E_{\text {unred }}$ contains endothelial cell lysate run unreduced, and demonstrates a band with an apparent molecular weight of $155 \mathrm{kD}$.
200

97

68

but binding to the lymphocyte cell line was minimal. Inhibition by anti-GPIb antibody was less effective with the smooth muscle cell line, suggesting some differences in the availability or affinity of the antibody for the GPIb molecule on these cells (data not shown).

\section{Discussion}

We have identified and isolated a GPIb-like protein from cultured human umbilical vein endothelial cells and from bovine aortic smooth muscle cells. It is of interest that in these cells, the protein appears to be functional, in that it is capable of supporting ristocetin-dependent $\mathrm{vWF}$ binding. The $K_{\mathrm{d}}$ observed for vWF binding in these studies agrees well with the $K_{d}$ previously published for vWF binding to the platelet surface $(21,24)$. The migration of the isolated GPIb-like molecule reduced and unreduced, in SDS-PAGE suggests that it is a single polypeptide chain with an intrachain disulfide bond or bonds. The GPIb-like molecule is reactive with a polyclonal antisera that was raised to reduced and alkylated platelet GPIb-alpha and therefore recognizes colinear amino acid domains. Reactivity of the GPIb-like molecule in endothelial cells and smooth muscle cells was also observed with a monoclonal antibody that was raised to the glycocalicin portion of GPIb-alpha. No evidence for the presence of GPIb-beta was seen in these studies, but it is difficult to exclude the presence of a beta chain entirely.

In platelets, the vWF-GPIb interaction is critical for initial platelet adhesion, and in clinical states of vWF deficiency or platelet GPIb deficiency, platelet function is abnormal (25). The biological role of the GPIb-like molecules in the two cell types we have studied is not yet defined, but it is interesting to speculate that under certain conditions, vWF binding to these vascular cells may initiate platelet adherence and promote thrombosis. Endothelial cells are known to synthesize and secrete vWF in a constitutive manner (26). In addition, vWF is secreted from stored pools of vWF in an activation dependent 


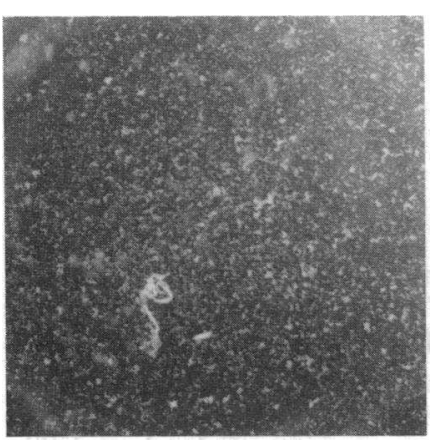

A

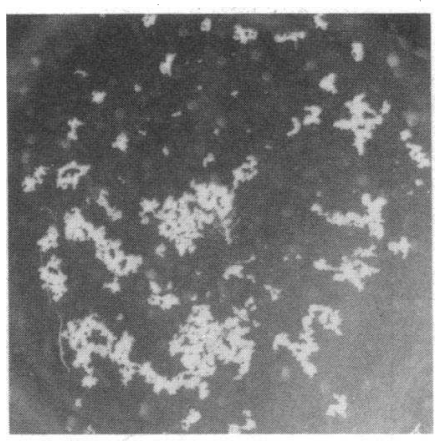

$\mathrm{B}$

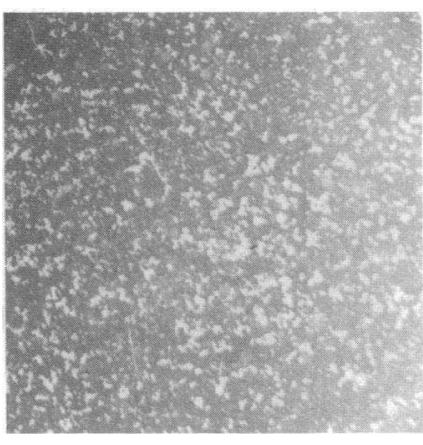

C

Figure 7. Ristocetin agglutination. Fixed endothelial cells in the presence of $1 \mathrm{mg} / \mathrm{ml}$ ristocetin alone (a), ristocetin $1 \mathrm{mg} / \mathrm{ml} \mathrm{and} 20 \mu \mathrm{g} / \mathrm{ml} \mathrm{puri}$ fied von Willebrand plasma $(b)$, ristocetin plus purified vWF plus $20 \mu \mathrm{g} / \mathrm{ml}$ monoclonal anti-GPIb (AP1) that inhibits ristocetin induced platelet agglutination $(c)$. Ristocetin agglutination of suspended endothelial cells is dependent on vWF and is inhibitable by a monoclonal anti-GPIb.

manner (27). In recent studies, vWF expression on the surface of thrombin stimulated cultured endothelial cells has been observed using fluorescence microscopy (28). In vivo, under conditions that lead to stimulation of endothelial cells and release of vWF, endothelial cell GPIb may mediate the expression of endogenous $\mathrm{VWF}$ on the cell surface in concentrations that favor platelet adherence. Endothelial cell GPIb might also play a role in thrombosis observed in patients with heparin-associated thrombocytopenia. Recently, antibodies with specificity for HUVEC have been described in patients with heparin-associated thrombocytopenia (29) and heparin-associated platelet aggregation in some patients may be dependent on platelet GPIb (30). It is possible that in some patients with heparin associated thrombocytopenia, antiendothelial cell antibodies are in fact reactive with endothelial cell GPIb.

The presence of a $210-\mathrm{kD}$ band in the endothelial cell immunoprecipitation experiments is of some interest. A $210-\mathrm{kD}$ GPIb-like molecule has been previously described in platelets (22), and may represent a precursor molecule. A patient with antibodies to this protein recently has been described who clinically manifested an acquired Bernard-Soulier syndrome (31). The function of this $210-\mathrm{kD}$ protein in platelets and in endothelial cells remains to be determined. The lower molecular weight species that we observed in immunoprecipitation experiments were likely associated with the immunoprecipitated 150-kD alpha chain, since they were not observed in the Western blots. It is tempting to speculate that in endothelial cells, the $210-\mathrm{kD}$ precursor molecule may be processed to the lower molecular weight GPI proteins: alpha, and beta, with a $60-\mathrm{kD}$ cleavage byproduct. Alternatively, the $60-\mathrm{kD}$ species

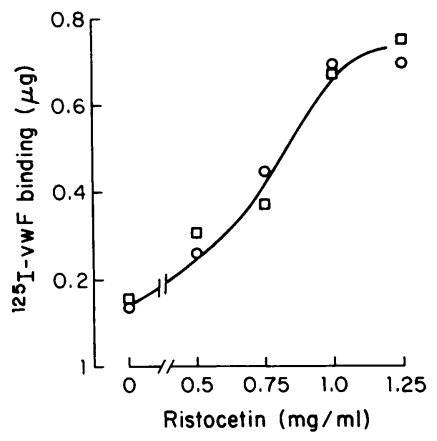

Figure 8. Ristocetin dependence of ${ }^{125}$ I-labeled vWF binding to human umbilical vein endothelial cells. Binding of ${ }^{125} \mathrm{I}-\mathrm{vWf}$ was examined over a range of ristocetin concentrations in the presence (open circles) or absence (open squares) of $0.02 \%$ bovine serum albumin. Maximal binding was obtained at $1.0 \mathrm{mg} / \mathrm{ml}$ ristocetin. may be a precursor of fully glycosylated GPIb alpha. A GPIb alpha-like molecule with an apparent $M_{\mathrm{r}}$ of 60,000 has been isolated from HEL cells $(32)$, and recently sequenced $(11,33)$. In HEL cells the $60 \mathrm{kd}$ molecule appears to correspond to an unglycosylated form of GPIb-alpha.

Recently, the glycoprotein complex IIb/IIIa, which functions on the platelet membrane as a fibrinogen receptor, has been described in several cell types (6-8). Preliminary sequence data supports the premise that IIb/IIIa belongs to a class of adhesive protein receptors that are distributed widely among many cell types (34). We have recently identified a glycoprotein that functions as a receptor for thrombospondin, a platelet alpha granule constituent with a broad tissue distribution. The thrombospondin receptor, which appears to be identical with platelet glycoprotein IV, is present not only in platelets, but also on endothelial cells, monocytes, as well as several tumor cell lines (35). These studies, as well as the observation that GPIb alpha is functional in endothelial cells and in smooth muscle cells, suggests that there are a number of adhesive protein receptors that mediate cell adhesion phenomena and that platelet aggregation may provide a useful paradigm for the understanding of these events. The role of GPIb in mediating adhesion in other cell systems may involve ligands other than vWF. The close association of GPIb with the cytoskeleton makes it a good candidate for a cell receptor in-

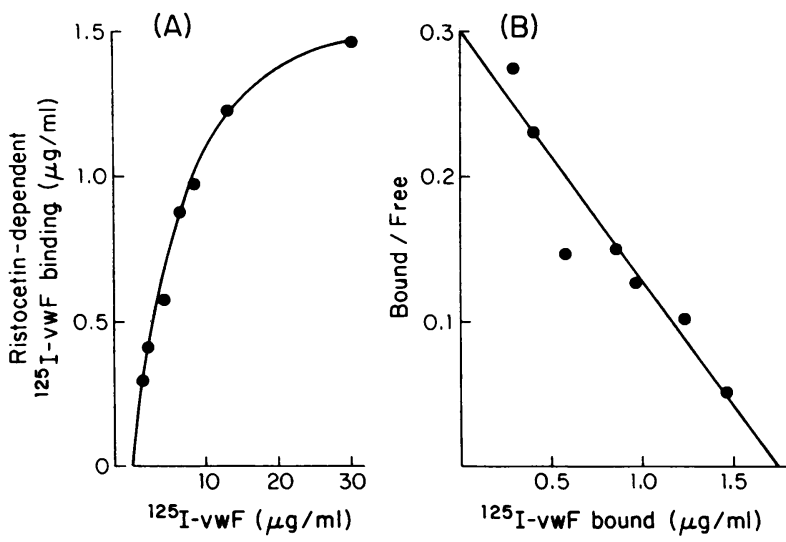

Figure 9. Endothelial cell ${ }^{125} \mathrm{I}-\mathrm{vWF}$ binding. Binding isotherm, (a). Scatchard plot $(b)$. 

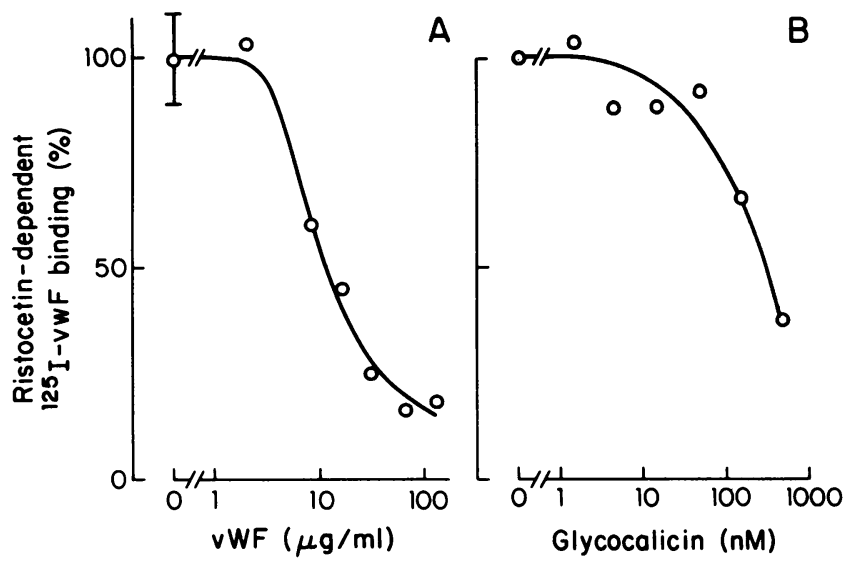

volved in the migration of cells. Similar receptor cytoskeleton links are important in other systems (3-5, 36-38). vWF or homologous ligands within the extracellular matrix or on other cells may mediate or modulate cell-substrate attachment and cell-cell interaction in developing organisms or in atherosclerosis, or in tumor cell metastasis.

\section{Acknowledgments}

We thank Dr. T. Kunicki (Milwaukee Blood Center) for his generous gift of AP-1 monoclonal antibody, and Dr. Z. Ruggeri for his generous gift of anti-glycoprotein Ib-alpha. The expert technical assistance of Ms. Barbara Ferris and Ms. Diana Contreras is gratefully acknowledged.

This research was supported by grant HL-18828 from the National Institutes of Health to the Specialized Center of Research in Thrombosis. A. Asch is the recipient of NIH Clinical Investigator Award HL-01567-02. B. Adelman is the recipient of NIH Clinical Investigator Award HL-01533. Additional support was provided by grants from the Council for Tobacco Research, USA, the Veterans Administration research program, the New York Community Trust, and the Sklarow Memorial Trust.

Note added in proof. Since the acceptance of this manuscript, the presence of endothelial cell GPIb has been reported by Sprandio et al. (39).

\section{References}

1. Phillips, D. R., and P. P. Agin. 1977. Platelet plasma membrane glycoproteins. Evidence for the presence of nonequivalent disulfide bonds using nonreduced-reduced two dimensional gel electrophoresis. J. Biol. Chem. 252:2121-2126.

2. Clemetson, K. J. 1985. In Platelet Membrane Glycoproteins. J. N. George, A. T. Nurden, and D. R. Phillips, editors. Plenum Publishing Corp., New York. 51-55.

3. Solum, N. O., and T. M. Olsen. 1984. Glycoprotein Ib in the Triton-insoluble (cytoskeletal) fraction of blood platelets. Biochim. Biophys. Acta. 799:209-220.

4. Solum, N. O., and Olsen, T. M. 1985. Effects of diamide and dibucaine on platelet glycoprotein $\mathrm{Ib}$, actin binding protein and cytoskeleton. Biochim. Biophys. Acta. 817:249-260.

5. Fox, J. E. 1985. Linkage of a membrane skeleton to integral membrane glycoproteins in human platelets. Identification of one of the glycoproteins as glycoprotein Ib. J. Clin. Invest. 76:1673-1683.

6. Fitzgerald, E. A., I. F. Charo, and D. R. Phillips. 1985. Human and bovine endothelial cells synthesize membrane proteins similar to human platelet glycoprotein IIb and IIIa. J. Biol. Chem. 260:1089310896.

7. Charo, I. F., L. A. Fitzgerald, and D. N. Phillips. 1985. Human smooth muscle cells and a fibroblast-like cell line (MG 63) express surface glycoproteins that are similar to platelet GPIIb and GPIIIa. Blood. 66 (Suppl. 1):1094a. (Abstr.)

8. Thiargarajan, P., S. S. Shapiro, E. Levine, L. Demarco, and A. Yalcin. 1985. A monoclonal antibody to human platelet glycoprotein IIIa detects a related protein in cultured human endothelial cells. $J$. Clin. Invest. 75:896-901.

9. Kohler, G., and C. Milstein. 1976. Derivation of specific antibody-producing tissue culture and tumor lines by cell fusion. Eur. $J$. Immunol. 6:511-519.

10. Montgomery, R. R., T. J. Kunicki, C. Taves, D. Pidard, and M. Corcoran. 1983. Diagnosis of Bernard-Soulier syndrome and Glanzmann's thrombasthenia with a monoclonal assay on whole blood. $J$. Clin. Invest. 71:385-389.

11. Titani, K., K. Takio, M. Handa, and Z. M. Ruggeri. 1987. Amino acid sequence of the von Willebrand factor-binding domain of platelet membrane Gycoprotein Ib. Proc. Natl. Acad. Sci. USA. 84:5610-5614.

12. Michelson, A. D., J. Loscalzo, B. Melnick, B. S. Coller, and R. I. Handin. 1986. Partial characterization of a binding site for von Willebrand factor on glycocalicin. Blood. 67:19-26.

13. Jaffe, E. A., R. L. Nachman, C. G. Becker, and C. R. Minick. 1973. Culture of human endothelial cells derived from umbilical veins: identification by morphologic and immunologic criteria. J. Clin. Invest. 52:2745-2756.

14. Jaffe, E. A. 1984. Culture and identification of large vessel endothelial cells. In The Biology of Endothelial cells. E. A. Jaffe, editor. Martinus-Nijhoff, The Hague, the Netherlands. 1-13.

15. Maciag, T., G. A. Hoons, M. B. Stemerman, and R. Weinstein. 1981. Serial propagation of human endothelial cells in vitro. J. Cell Biol. 91:420-426.

16. Thornton, S. C., S. N. Mueller, and E. M. Levine. 1983. Human endothelial cells: use of heparin in cloning and long-term serial cultivation. Science (Wash. DC). 222:623-625.

17. Becker, C. G., D. P. Hajjar, and J. M. Hefton. 1985. Tobacco constituents are mitogenic for arterial smooth muscle cells. Am. J. Pathol. 120:1-5.

18. Weiss, H. J., L. W. Hoyer, F. R. Rickles, A. Varma, and J. Rogers. 1973. Quantitative assay of a plasma factor deficient in von Willebrand's disease that is necessary for platelet aggregation. Relationship to Factor VIII procoagulant activity and antigen content. $J$. Clin. Invest. 52:2708-2716.

19. Brinkhous, K. M., and M. S. Read. 1978. Preservation of platelet receptors for platelet aggregating factor/von Willebrand factor by air drying, freezing or lyophilization: new stable platelet preparations for von Willebrand factor assays. Thromb. Res. 13:591. 
20. McConahey, P. J., and F. J. Dixon. 1966. A method of trace iodination of proteins for immunological studies. Int. Arch. Allergy Appl. Immunol. 29:185-189.

21. Kao, K., S. V. Pizzo, and P. A. Mckee. 1979. Demonstration and characterization of specific binding sites for Factor VIII/von Willebrand fator on human platelets. J. Clin. Invest. 63:656-664.

22. Nachman, R. L., T. Kinoshita, and B. Ferris. 1979. Structural analysis of human platelet membrane glycoprotein I. Proc. Natl. Acad. Sci. USA. 76:2952-2954.

23. Casonato, A., F. Fabris, M. Vicariotto, and A. Girolami. 1985. The evaluation of factor VIII antigen by means of a simple slide test. Am. J. Clin. Pathol. 84:107-111.

24. Morisato, D. K., and H. R. Gralnick. 1980. Selective binding of the Factor VIII/von Willebrand factor protein to human platelets. Blood. 55:9-15.

25. Nurden, A. T., and J. P. Caen. 1979. The different glycoprotein abnormalities in thrombasthenic and Bernard-Soulier platelets. Semin. Hematol. 16:234-250.

26. Jaffe, E. A., L. W. Hoyer, and R. L. Nachman. 1974. Synthesis of von Willebrand factor by cultured human endothelial cells. Proc. Natl. Acad. Sci. USA. 71:1906-1909.

27. deGroot, P. G., M. D. Gonsalves, C. Loesberg, M. F. vanBuulWortelboer, W. G. vanAken, and J. A. vanMourik. 1984. Thrombininduced release of von Willebrand factor from endothelial cells is mediated by phospholipid methylation. Prostaglandin synthesis is independent of phospholipid methylation. J. Biol. Chem. 259:1332913333.

28. Ribes, J. A., C. W. Francis, and D. D. Wagner. 1986. Fibrin stimulates rapid release of von Willebrand factor from endothelial cells. Circulation. 74 (Suppl. II):1621a. (Abstr.)

29. Cines, D. B., A. Tomaski, and S. Tannenbaum. 1987. Immune endothelial-cell injury in heparin associated thrombocytopenia. $N$. Engl. J. Med. 316:581-588.

30. Adelman, B., M. Sobel, Y. Fujimura, Z. M. Ruggeri, and T. S. Zimmerman. 1986. Platelet glycoprotein Ib is a binding site that participates in platelet aggregation in heparin associated thrombocytopenia. Clin. Res. 34:449a. (Abstr.)
31. Stricker, R. B., D. Wong, S. R. Saks, L. Corash, and M. A. Shuman. 1985. Acquired Bernard-Soulier syndrome. Evidence for the role of a 210,000-molecular weight protein in the interaction of platelets with von Willebrand factor. J. Clin. Invest. 76:1274-1278.

32. Kieffer, N., N. Debili, A. Wicki, M. Tieux, A. Henri, Z. Michal, J. Breton-Gorius, W. Vainchenker, and K. J. Clemetson. 1986. Expression of platelet glycoprotein Ib alpha in HEL cells. J. Biol. Chem. 261:15854-15862.

33. Lopez, J. A., D. W. Chung, K. Fujicawa, F. S. Hagen, T. Papayannopoulou, and G. J. Roth. 1987. Cloning of the alpha chain of human platelet glycoprotein Ib: a transmembrane protein with homology to leucine-rich alpha 2-glycoprotein. Proc. Natl. Acad. Sci. USA. 84:5615-5619.

34. Charo, I. F., L. A. Fitzgerald, B. Steiner, S. C. Rall Jr., L. S. Bekeart, and D. R. Phillips. 1986. Platelet glycoproteins IIb and IIIa: evidence for a family of immunologically and structurally related glycoproteins in mammalian cells. Proc. Natl. Acad. Sci. USA. 83:83518355.

35. Asch, A. S., J. Barnwell, R. L. Silverstein, and R. L. Nachman. 1987. Isolation of the thrombospondin membrane receptor. J. Clin. Invest. 79:1054-1061.

36. Wheeler, M. E., A. C. Cox, and R. C. Carroll. 1984. Retention of the glycoprotein IIb-IIIa complex in the isolated platelet cytoskeleton. Effects of separable assembly of platelet pseudopodal and contractile cytoskeletons. J. Clin. Invest. 74:1080-1089.

37. Duband, J. L., S. Rocher, W. T. Chen, K. M. Yamada, and J. P. Thiery. 1986. Cell adhesion and migration in the early vertebrate embryo: location and possible role of the putative fibronectin receptor complex. J. Cell Biol. 102:160-178.

38. Brown, S. S., H. L. Malinoff, and M. S. Micha. 1983. Connectin: cell surface protein that binds both laminin and actin. Proc. Natl. Acad. Sci. USA. 80:5927-5930.

39. Sprandio, J. D., S. S. Shapiro, P. Thiagarajan, and S. McCord. 1988. Cultured human umbilical vein endothelial cells contain a membrane glycoprotein immunologically related to platelet glycoprotein Ib. Blood. 71:234-237. 